
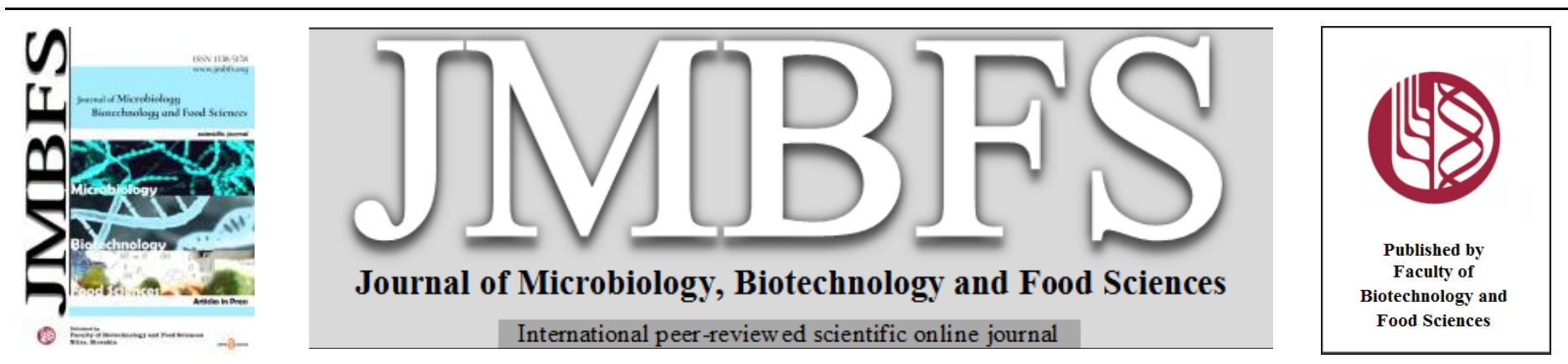

\title{
EXTRACELLULAR ALKALINE PECTINASES PRODUCTION: A REVIEW
}

\section{Pitambri THAKUR ${ }^{1}$,Abhishek K. SINGH ${ }^{2}$, Manjeet SINGH ${ }^{l}$, Gunjan MUKHERJEE ${ }^{I^{*}}$}

Address(es):

${ }^{1}$ University Institute of Biotechnology, Chandigarh University, Mohali, Punjab, India.

${ }^{2}$ University Institutes of Engineering, Department of Biotechnology Engineering, Chandigarh University, Mohali, Punjab, India.

*Corresponding author: gunjanmukherjee@gmail.com

https://doi.org/10.55251/jmbfs.3745

\section{ARTICLE INFO}

Received 21. 9. 2020

Revised 17. 12. 2021

Accepted 22. 12. 2021

Published 1. 4. 2022

Regular article OPEN $\partial_{\text {AcCESS }}$

\begin{abstract}
Pectinases are most significant enzymes of commercial sector. Among all the commercially produced industrial enzymes, pectinases occupy $25 \%$ share in the overall enzyme market. Pectinases have wide applications in various processes such as fruit juice clarification, wastewater remediation and textile and paper industry etc. Pectinase is most suitable environment friendly tool of nature for sustainable development. Although, pectinases alike many other commercial enzymes are facing the imperative of low harvest and yield. Hence, pectinases have been the objective of research to accomplish the commercial scale articulation levels. To find unique physicochemical properties of pectinases often microbial pectinases are utilized among all the natural sources due to ease in production. Present study primarily centers on the different types of recent techniques for the alkaline pectinases production and optimization strategies advancement for high production yield. For achieving higher production of the extracellular alkaline pectinases by utilizing basic fermentation media and simple molecular devices along with genetic engineering approaches are included in the present study. For the improved alkaline pectinase production advanced genetic engineering techniques such as gene cloning, tools of r-DNA technology and cell immobilization technique are discussed.
\end{abstract}

Keywords: Alkaline Pectinases; Optimization strategies; Genetic engineering; Fermentation media

\section{INTRODUCTION}

In the mid nineteenth century, enzyme turned up and since then they are being spaciously used in several industrial tasks. Enzymes are tremendously effective and very particular biocatalyst. There is an expansion in the demand of using biotechnological processes in place of conventional processes. Many biotechnological processes include microorganisms and enzymes such as pectinases, xylanases, cellulases, mannase $\alpha$-galactosidase, lactases and liginases which are eco-friendly and cost effective (Hoondal et al., 2002). Basically, pectins are high molecular weight acid polysaccharides, initially containing $\alpha-(1-4)$ linkage D-galacturonic acid residues with a short number of rhamnose residues in the main chain and arabinose, galactose, and xylose on its side chain. An enzyme family which generate breakdown of the glycosidic bonds in the pectin can also be called pectinase which is a generic name (Rangarajan et al., 2010). Plant pathogens build various cell wall degrading enzymes to strike on target cells, which clear the path for entrance and evolution of pathogen in host tissue. These phyto pathogenic enzymes contain pectinases, cellulases and proteases. Pectinases take part in the breakdown of pectins. Based on mode of action and substrates used, pectinases are categorized as pectin esterase (E.C.3.1.1.11), Hydrolases (pectin methyl galacturonase (E.S 3.2.1.41) and polygalaturonases (E.S 3.2.1.15), and Lyases (pectin lyase) (E.C. 4.2.2.10) and pectate lyase (E.C. 4.2.2.2).

Pectinase are divided into endo and exo pectinases relying on random or endwise cleavages ( $\mathbf{L i}$ et al., 2012). Based on the $\mathrm{pH}$ requirement, pectinases are divided into alkaline and acidic pectinases. There are many uses of acidic pectinases in withdrawal and fruit juice clarification. These are being broadly utilized in biopreparation of cotton fabrics, for steeping the plant fibres like flax, hemp and jute, enzymatic polishing of cotton blended fabrics, to find a solution for mechanical pulp bleaching retention problems, and for upgrading the quality of black tea (Sharma and Satyanarayana, 2006). In spite of the fact that alkaline pectinases are used in industrial works, but it is essential to purify and get all the information of biochemical characteristics of these enzymes for better understanding about the structure, and mechanism of action (Li et al., 2012). Microbial production of pectinases has been described in solid state fermentation and submerged fermentation. Solid state fermentation is better than submerged fermentation in terms of practical and economical advantages but has a limited adoption (Zou et al., 2014).

\section{Pectinase and its types}

Pectinases are the enzymes which hydrolyzes the pectic substances. Pectinases includes polygacturonases, pectate lyases, pectinesterases and pectin lyases relying on the mode of action (Alkorta et al., 1998). Pectinases are mostly used in food industries for clarifying fruit juices and wines to improve the level of cloudiness, haze as well as utilized to produce tea, coffee, and oil extraction. Alkaline pectinases are used to separate the mucilage from coffee beans and to speed up fermentation of tea (Willats $\boldsymbol{e t}$ al., 2006). They are also used for striping of plants fibers, textile and paper industry, animal feed and wastewater treatments because of their capability to demean pectic polymers (Demir and Tarl, 2014). According to Taskin (2013) various types of pectinases endo and exopolygalacturonase are most important and broadly applicable pectinases and contribute as $25 \%$ of industrial sales of enzymes globally. This will continue to grow up.

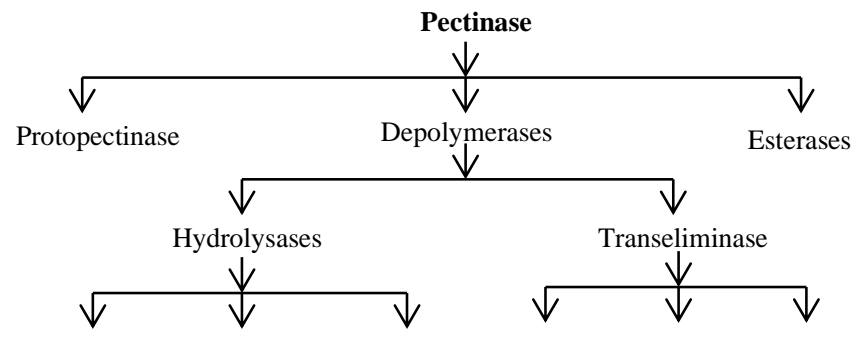

Polymethylgalacturonase Rhamanogalacturonase Pectate lyase Polygalacturonase Pectin lyase Rhamanogala cturonan lyase 


\section{Alkaline Pectinases Occurance}

Pectinases are delegated in the higher plants in which they are indulged in alteration of pectinaceous materials in the time of natural maturing of various fruits. Pectinases can be acquired from different plant, animal, and microbia sources, but to satisfy the commercial needs enzymes are to be acquired from microbial sources. Due to various benefits of microorganisms such as biodiversity, faster growth represents a good resource of these enzymes (Amin et al., 2017). To produce this enzyme, which is an important enzyme for industry purposes, 30 various genus of fungi, bacteria and yeasts had been identified (Favela-Torres $\boldsymbol{e t}$ al., 2006). Origin of microbial toolbox is from the filamentous fungi, yeast, nonfilamentous and filamentous bacteria. Alkaline pectinases are secreted by bacteria strains, where as those pectinolytic derived from fungus are acidic in nature Specifically, filamentous fungi are the best resource of commercial pectinolytic biocatalysts. It represents all members of polygalacturonic acid. It defines genes and shows differences in accordance with the cleavage rate, substrate specificity, temperature and pH optima for activity (Jacob, 2009). Enzyme's status from this fungus lies on the 97 pectinase genes which were glossed and 60 new genes that are generated from the whole genome of Aspergillus niger (Khan et al., 2013) Genus Aspergillus other species are also identified in the studies for the biosynthesis of the pectinases, various other acidic natured pectinase making fung and yeast are generally from genus Rhizomucor sp., Pencillinum sp., Rhizopus sp. Aureobasidium sp.,Trichoderma sp., Thermotoga sp., Candida sp., Saccharomyces sp., Pichia sp., Kluyveromyces sp., Schizosaccharomyces sp., whereas, Klebsiella sp., Bacillus sp., Pseudomonas sp. and Cryptococcus sp., have been selected for alkaline pectinase production. Various types of pectinases made by bacterial, fungal and yeast cultures are present at commercial scale (Kashyap et al., 2001). Pectinase enzyme is also produced by bacteria belonged to species of Enterobacter (Enterobacter sp. MF41, Enterobacter sp. MF84, and Enterobacter sp. MF90 Enterobacter sp. MF84), Erwinia (E. carotovora and E. chrysanthemi) (Matsumoto et al., 2003), Pseudomonas (Sohail \& Latif, 2016), Bacillus. and, Streptomyces (Ramirez-Tapias et al., 2015) Lactobacillus (Karam \& Belarbi, 1995) etc. Many researchers reported that, pectinolytic properties of Bacillus strains are selected as the major source of pectinase enzymes (Kavuthodi et al. 2015; Sohail \& Latif, 2016, Kavuthodi and Sebastian, 2018). Microbial strain are selected on various measures like number of pectinases produced, type of fermentation technique, thermostability properties and $\mathrm{pH}$ of enzymes and genotype of the microbial strain (Favela-Torres et al., 2006).

\section{Substrate for alkaline pectinase}

Pectin is the well layered homo polysaccharide appearing in the primary cell walls and middle lamella of terrestrial plants, inhabited in $1 / 3$ of the dry mass of plant tissue (Gupta et al., 2008). It consists of long galacturonic acid chains along with residues of carboxyl groups and methyl esters. A pectic substance forms the important part of middle lamella and these substances are omni-present in plant kingdom. Pectic acid is the main chain of pectin which is half methyl-esterified-1, 4-D galacturonan. Pectin substances are amorphous with polymerization of 200400. Substituents are located either on C-2 or C-3 locus of main chain. They can be sugar or non-sugar, based on sources of pectic substances, kind of branching differentiates. In the initial stages of rise in immature enlarging cell walls there appears production of pectic substances in the golgi apparatus by UDP-Dgalacturonic acid (Hoondal et al., 2002; Ali et al., 2013). As compared to young actively growing tissues less than $1 \%$ of pectin substances are present in higher plants which are quite low. These mainly contribute to vegetables and fruits but comprise a huge part of algal biomass up to $30 \%$. Pectic substances are divided as pectinic acids, pectic acids, pectin, and protopectin. Pectic acids are basically a complex designation which is given to pectic substances in colloidal polygalcturonic acids is more and there are independent of methoxy groups salts of pectic acids can be acidic pectates. Pectic acid consists of $75 \%$ methylated galacturonate units. Pectinic acid can be used to produce gels containing sugars and acids only under satisfied conditions. Protopectin is located in the middle lamella serving as a cement to bind cells altogether in the cell wall. Pectinic acid is a water-insoluble parent pectin substance. It produces pectin and pectinic acids on restriction hydrolysis. This acid is insoluble in water due to its high molecular mass, formation of ester bond in between carboxylic and hydroxyl group, and bonding of salt between the basic groups and carboxyl group of proteins. The model has been made for chemical shape of protopectin into which neutralized sugar side are organized into blocks unconnected by unsubstantial parts consisting exclusively almost galacturonic acid residues (Yoshitake $\boldsymbol{e t}$ al., 1994). It is soluble in nature. It is also able to form gels with sugars and acids under certified conditions. According to Thakur and Mukherjee (2021) different agricultural waste such as lemon peel, apple waste, rice husk, wheat bran and sugar cane bagasse etc can utilized for the production of pectinase. Residues from production of fruit juices, citrus fruits and apple pomace are used for manufacturing pectin (Alkorta et al., 1998).

\section{Sources of Pectinases}

Pectinases have variety of sources for example yeast, actinomycetes, bacteria and fungi (Hoondal et al., 2002). Basic pectinases are of two types: alkaline and acidic pectinases. Both the types have various industrial applications like fruit juice clearance and wastewater treatment, degumming of fibers such as hemp, flax, and jute etc. (Tanabe $\boldsymbol{e t}$ al., 1988). And these fibers are used for various modern potential purposes such as ropes, nets etc. Various microbial sources of alkaline pectinases are Bacillus licheniformis (Kapoor et al, 2000), Bacillus subtilis (Ward and Forgarty, 2010), Aspergillus fumigates (Phutela et al, 2005) Wickerhamomyces anomalus (Martos et al, 2013), and actinomycetes etc (Bruhlman et al, 1994).

\section{Alkaline pectinases production strategies}

For the production of pectinases from the microorganisms, the most common strategy is fermentation techniques. Certain strategies such as submerged fermentation $(\mathrm{SmF})$, entire cell immobilization and strong state aging are used for pectinase production from various microbial sources (Couto and Sanroman, 2006).

\section{Fermentation Techniques}

Major soluble pectinase producing varieties are Bacillus and Pseudomonas sp. and at the commercial scale around $90 \%$ of enzymes are produced via submerged fermentation (Kashyap, 2001; Pedrolli and Carmona, 2010). Also, the SSF procedure is a static procedure without industrial vitality uses. In disparity, the SmF cultures fill in as homogeneous frameworks requiring expansive vitality uses to adapt to high oxygen requirements (Viniegra-Gonzaleza et al., 2003). SSF is used from last two decades to produce industrially important enzymes (Couto and Sanroman, 2006). SSF in comparison to SmF produces high enzyme titer (Hoondal et al., 2002). And sadly, no extensive reports clarifying the explanation behind this are available. This absence of data makes troublesome any evaluation regarding the value of one process versus the other. For the biosynthesis of enzymes, less common technique immobilized cell culture offers many advantages. It is used in liquid-state fermentations using immobilized cells because it provides reusability and catalytic stability of enzyme (Hoondal $\boldsymbol{e t}$ al., 2002; Kapoor and Kuhad, 2000)

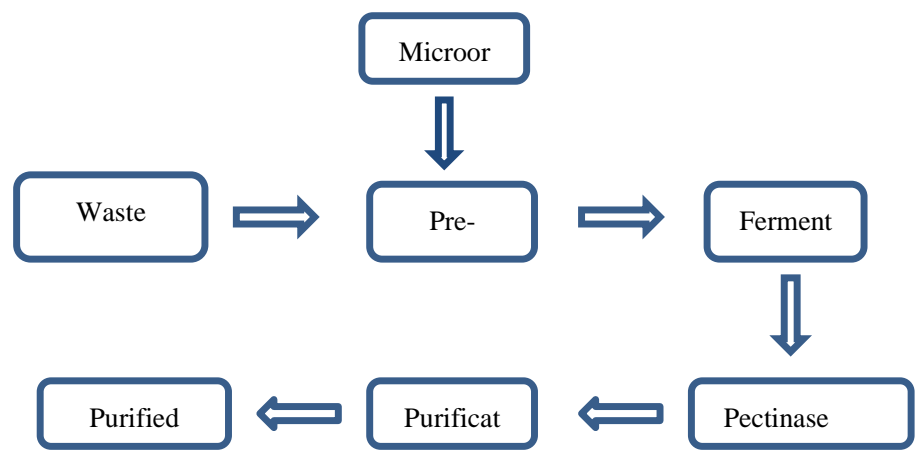

Figure 2_Overall process scheme for pectinase production from waste or pure substrate

\section{Submerged Fermentation}

To produce extracellular microbial enzymes at industrial scale, submerged fermentation is the matured process. Nonetheless, the yield of the catalyst relies upon strain type utilized and a few physical and nutritional factors, for example, $\mathrm{pH}$, temperature, a substrate, incubation time, extra dietary sources, air circulation, fomentation, and extraction techniques etc. Under submerged fermentation many reports are available for pectinase production. Bacterial cultures lead to the production of alkaline pectinase and yeast pectinases are of acidic nature. Various studies unravel fungal strain alkaline pectinases production under submerged fermentation (Alimardani-Theuil et al., 2011). Various fermentation- processing factors were optimized by Glinka and Liao (2011) and recorded highest production $329 \mathrm{U} / \mathrm{mL}$ of pectin methyl esterase. $21 \mathrm{U} / \mathrm{mL}$ pectinase titer was observed by Padma et al., (2011) under liquid-state fermentation using orange peel. $1015 \mathrm{U} / \mathrm{mg}$ pectinase with PGase at neutral $\mathrm{pH}$ from Bacillus species was produced by Rehman et al., (2012). And1122 U/L enzyme titers from Streptomyces species was produced by Saadoun et al., (2013). Also, in submerged fermentation utilizing food waste reported $24.18 \mathrm{U} / \mathrm{mL}$. After utilizing cheaper growth substrate increased biosynthesis of pectinase is observed particularly for textile industry (Ahmed $\boldsymbol{e}$ al., 2016). By using agro-industrial waste PGase enzyme using various isolated bacterial strains was produced (Jahan et al., 2017). 


\section{Solid State Fermentation}

In the present era of biotechnology due to certain advantages solid state fermentation is exceptionally enticing specified underneath (Jacob, 2009; Pedroll and Carmona, 2010). It permits the use of cost-effective agro-waste substrate for the growth of microbes. As compare to submerged fermentation, solid-state fermentation has better and enhanced properties. Also, less contribution of energy is required. It is sustainable and green with high generation of microbial metabolites. SSF is very promising tool for enzymes extraction from fungi. Although, there are a few reports exhibiting the development of microscopic organisms and about great yields of the enzymes. The last yield of the pectinases relies upon a few procedure factors like sort of strain utilized, and other parameters such as extra nourishing sources, $\mathrm{pH}$, temperature, incubation time and type of substrate etc. (Li et al., 2005; Ahlawat et al., 2009). Sixty fungal strains from the spoiled products of the soil observed as the high producer of pectinase with 74.0 $\mathrm{U} / \mathrm{mL}$ (Sandri et al., 2013). Further, unique working factors, for example, maturation time, temperature, $\mathrm{pH}$, and dampness content were applied as onevariable-at-time measurable strategy. Alkaline pectinase B. subtilis ZGL14 activity was optimized using RSM with Box-Behnken design (Yu et al., 2017).

\section{Factors Affecting Pectinases Production}

\section{Nitrogen source}

The effects of various nitrogen sources (organic and inorganic) on pectinase production have extensively studied. Rasheedha et al. (2010) observed that ammonium sulphate did influence production of Penicillium chrysogenum pectinase. Hours and coworkers (1988) reported that lower levels of inorganic nitrogen sources (K2HPO4) in growth medium was not influence the pectinase production. Additionally, Patil and Dayanand (2006) found that ammonium phosphate and ammonium sulphate has enhanced the pectinase production. Sapunova (1990) found that malt sprouts and ammonium salts stimulated the pectinolytic enzyme production in Aspergillus alliaceus BIM-83. Fawole and Odunfa (2003) reported that ammonium sulphate and ammonium nitrate have the best nitrogen source for the production of pectinase from Aspergillus niger. Reda et al. (2008) reported that the highest production of pectin depolymerase by Bacillus firmus-I-10104 in the presence of peptone. In addition, Vivek et al., (2010) reported the organic nitrogen sources showed higher endopolygalacturonase, exopolygalacturonase activities than inorganic nitrogen sources.

\section{Carbon source}

Teixeira et al. (2000) found that the best carbon sources for high pectinolytic activities from Aspergillus japonicus 586 were $0.5 \%$ pectin (pectinesterase), $0.2 \%$ pectin and $0.2 \%$ glycerol (endopolygalacturonase) and pectin associated to glucose (exopolygalacturonase). Pectinesterase activity was susceptible to catabolic repression with high pectin, glucose and saccharose concentrations. Aguilar and Huitron (1987) reported that the enhanced the production of pectinases from A niger by the presence of glucose or saccharose association with pectic in low concentrations. Fawole and Odunfa (2003) observed that pectin and poly galacturonic acid enhanced the pectinase production. In addition, the highest pectinase production was observed using wheat bran while pure pectin give the highest pectin depolymerase production (Phutela et al., 2005).

\section{Immobilized Cell Culture}

The microbes on diverse inert polymeric solid supports gives different advantages like to use them again; distinction of product without presence of microbes, distinction of from biomass produces better enzymatic stability (Moreno-Garcia et al., 2018). A wide heterogeneity of nature such as chitin and carrageenan, agaragar, alginate, collagen, chitosan and synthetic polymers such as polyurethane, polyacrylamide, and polyethylene glycol are being regarded as assisting resources But ordinary biopolymers had resulted better in immobilization despite their biocompatibility attributes (Angelim et al., 2013). In both solid and liquid state complete immobilization of cell on polyurethane foam (PUF) as immovable assistance and the attention of many researchers was derived into this (DiazGodinez et al., 2001). In the procedure of changing immobilization on polyurethane foam includes the immunization of sterile fermenter system containing motionless parts of PUF. When immunization is done, the germination of cell appears in a different way on the facet of PUF. This leads to immobilization of cells on the surface of PUF. Several micro-floras are employed in immobilization on PUF surface effectually (Hoondal $\boldsymbol{e t}$ al., 2002). The complete immobilization of cell of Bacillus bacterium on PUF gave favourable outcomes also attained 1.5- folds improvement in enzyme produced under solid state fermentation than submerged fermentation (Kapoor and Kuhad, 2000; Gophanea et al., 2016). To compare exo-pectinase produced by SSF and SmF, immobilization of Aspergillus niger cells on polyurethane cells were used (DiazGodinez et al., 2001). Because of superior biomass production unaccompanied by catabolite repression, probably the higher enzyme yield was appeared in SSF. The bioprocess cost is decreased due to immobilization technology. It gives permission to personalize target products. But execution of immobilized cells in industries is still not overcomes (Berbegal et al., 2017). Attention must be given on long term preservation of immobilized cells for future purposes. New bioreactors and bioprocesses should be made that are not of complex nature, cheap and flexible and which can also be scaled up (Nedovic et al., 2015). Solid supports which are being used must also be inexpensive, eco-friendly, good quality for better industrial exploitation (Moreno-Garcia et al., 2018)

\section{Production through genetic engineering}

In the modern biotechnology era, tools of r-DNA technology like mutation, gene cloning etc. have captivated the attention of researchers to produce enzymes that can be applied in industries. These techniques had helped a lot to scientists to get all the information of a specific gene of interest and achieve required overexpression and expression of a particular selected protein. Enzymes can be widely used in industries. That is why; scientists had focused on the study of these enzymes from past many years. Enzymologists are benefitted through genetic engineering as it gives different techniques to manufacture a specific enzyme on industrial scale at a low cost. Different pectinolytic genes are cloned and then expressed in wide variety of organisms to produce homologous and heterologous expression with low cost, time, and energy (Goncalves et al., 2012; Almeida et al., 2003). High yield of pactinases are attained through genetically engineered construct of different stains such as $P$. griseoseum. Bacillus subtilis was utilized for the advanced level extracellular production of alkaline polygalacturnonate lyase (PGL) with gene expression and PGL titers raised to $632.6 \mathrm{U} / \mathrm{mL}$ (Zhang $\boldsymbol{e}$ al., 2013). The homologous over-expression in B. subtilis strain of bacteria enhanced the yield of polygalacturonate lyase and with $2138 \mathrm{U} / \mathrm{mL}$ attained the highest yield of this enzyme (Zou et al., 2013). The recombinant expression of Aspergillus in $P$. pastoris concluded maximum yield of $2408.70 \mathrm{U} / \mathrm{mL}$ after utilizing batch fermentation of high cell density and it observed the yield was 4.8 folds higher (Abdulrachman et al., 2017).

\section{Optimizations strategies for the production of alkaline pectinases}

Pectinases production are widely influenced by the cultivation conditions, constituents of growth medium, $\mathrm{pH}$, aeration, temperature, the supplementary nutrients (salts, nitrogen and carbon sources) type of strain, moisture, and inducers (Amin et al., 2017). Agriculture food industry plays a vital role as it provides all the required nutritional ingredients for the growth of microbes for biosynthesis of pectinases. US department of energy stated that approximate 500,000,000 tons of commercial waste materials takes place in USA per year. Most of this heap of agriculture and food waste is discarded in open place. But biotechnologies came with a theory to utilize this in various processes of biotechnology with focus of on fermentation as well as bio-catalysis principles in a comfortable way (Bilal $\boldsymbol{e t}$ al. 2017; Djordjevic et al., 2017). Enzymes are part of this which is being produced through fermentation of agro-food wastes with microbial technology (Bilal $\boldsymbol{e t}$ al. 2015). As fermentation processes are influenced by type of substrates, so severalagro-industrials left over can be processed through optimization. Various agro-food waste like rice bean, wheat bran, fruit peels, leftovers etc. are utilized in industries to produce various types of enzymes (Munir $\boldsymbol{e t}$ al., 2015). This agro based waste material is rich in pectin and used as important natural substrates for pectinase production (da Silva et al., 2005; Favela-Torres et al., 2006). Severa authors cherished the use of this waste material as fermentation food stuffs in fermentation biotechnology (Bilal et al., 2015). Several other synthetic mediums like starch, sugar, etc and complex components played an important role to fulfill the nutrient requirements of the growth of micro-organisms and used in pectinase expression (Teixeira et al., 2000; Goncalves et al., 2012). The synthetic media can be utilized to manufacture pectinolytic enzymes (Sandri $\boldsymbol{e t}$ al., 2013; Zou $\boldsymbol{e t}$ al., 2013). These media mostly used to get proper production of enzymes. Various techniques like synthetic based medium and its optimizations to use the agro-waste to get sufficient yield of enzymes are being made by researchers. Some of the scientists tend to obtain the protein expressions by combining the genetic engineering with enzyme biotechnology (Zhang et al., 2013).

To obtain a crude pectinase, the fermentation medium has filtered using dry, preweighed Whatman filter paper, refrigerated centrifuged. Supernatant is collected for partial purification of pectinase. Crude pectinase is partial purified by using ethanol, ammonium sulphate precipitation (Barman et al. 2015). Pectinase has purified through gel filtration chromatography on Sephadex G 150 and ion exchange chromatography using DEAE-Sephacel (Kashyap et al., 2000).

\section{Optimization of Bacterial Strains}

SmF are basically used for microbial enzyme production. During fermentation, they need high water potential. Reports by author's states their consumption in solid state fermentation under ratios of high moisture and amended the procedure to acquire advantages of enhanced metabolites features given by SSF (Kashyap et al., 2003; Li et al., 2005). The manufacture of pectinase efficiently improved by Bacilius sp. due to various substrates generally solid, nitrogen and carbon, salts, and additional vitamin. In fermentation period, yield of pectinase is improved by $75 \%$ for 36 hours at $37{ }^{\circ} \mathrm{C}$ due to use of amalgamation of neurobin at $27 \mu \mathrm{L} / \mathrm{g}$ 
(Kashyap et al., 2003). A bacterial strain which was recently secluded, B. gibsoniiS-2 for optimizing yield of alkalinated pectinase utilizing pulp of sugar beet acquired $3600 \mathrm{U} / \mathrm{g}$ after $48 \mathrm{~h}$ at $35^{\circ} \mathrm{C}$ of incubation (Ouattara et al., 2011) The fermentation media additive 1 physical variant of $\mathrm{pH}$ and 3 dummy variant with the help of Placket-Burman design. Optimization of procedure concluded in 41-times of improvement in pectinase yield by B. Pumilus (Sharma and Satyanarayana 2006). Murugan et al, (2020) reported pectinase production from Bacillus species with $3.40 \mathrm{mg} / \mathrm{ml}$ of total protein and $484.70 \mathrm{U} / \mathrm{mg}$ of specific enzyme activity. In characterization studies, the pectinase demonstrated good activity at $\mathrm{pH} 6.0$ and $40^{\circ} \mathrm{C}$. Also, the bacterial strain showed maximum growth when the medium $\mathrm{pH}$ was 7.0 and incubated $37^{\circ} \mathrm{C}$.

\section{Optimization of Yeast Strains}

The two kinds of yeasts included in the production of pectinolytic enzymes are one group which is constitutive i.e. cannot use pectic substances as carbon source Present complex of yeast helps in secreting endo-polygalacturonases. The next group surrounds the yeasts such as filamentous fungi which can release pectinase on induction through the usage of pectinacious material, giving a more compounded enzymatic system in them. This complex is half constitutive. Candida boidinii and C. albidus have these features. Hence both the groups possess different origin of pectinases. These behaviors are disclosed by evaluating the origin of various pectin genes in yeasts. Yeast pectinases are extracellular in nature Statistics based strategy of optimization for the better yield of pectinase using genetically modified yeast with grape skin as a source of carbon (Arevalo-Villena et al., 2011; Zhou et al., 2011). Maximum pectinolytic activity by using raw fruit as a substrate at $5^{\circ} \mathrm{C}$ was observed by Padma et al., (2011). Exo-polygalacturonase recorded yield $28.6 \mathrm{U} / \mathrm{mL}$ from immobilized cells and $26.9 \mathrm{U} / \mathrm{mL}$ from free cells For 14 and 18 cycles the immobilized cell was securely used and at the end of 18 cycles recorded for polygalacturonase was a maximum yield 503.1 U/Ml (Taskin, 2013).

\section{Optimization of fungal strains}

The agriculture food industrial effluents are utilized much appropriately by fungal strains to produce series of microbial metabolites. These are a great contribution of authors in fungal species culturing to produce pectinases. The two important factors for statistical yield of proper amount of $29.093 \mathrm{U} / \mathrm{g}$ pectinase were two staged optimizing strategy which utilizes D-optimal and central composite design under solid state fermentation employing Aspergillus niger inoculums an incubating duration (Ustok et al., 2007). After fermenting for 5 days, production of exo-polygalacturonase $(1450 \mathrm{U} / \mathrm{g})$ was successfully acquired by utilizing oil cake of pumpkin as substrate of water activity of 0.9232 (Pedrolli and Carmona, 2010). The fermentation medium optimization used peel of orange as substrate by Fusarium solani for the improved production with peptone and glucose at $1 \%$ level was observed 102.21 U/g (Hamid et al., 2008). Two distinct substrates and strains of A. niger to attain the highest pectinase quantity was observed in bran of wheat resulted better than pectin (Khairnar $\boldsymbol{e t}$ al., 2009). Enshasy et al, (2018) reported pectinase production from Aspergillus niger of $109.63 \mathrm{U} / \mathrm{mL}$, which was about $10 \%$ higher than the uncontrolled $\mathrm{pH}$ culture. Furthermore, fed-batch cultivation using sucrose as a feeding substrate with a rate of $2 \mathrm{~g} / \mathrm{L} / \mathrm{h}$ increased the enzyme production up to $450 \mathrm{U} / \mathrm{mL}$ after $126 \mathrm{~h}$. Qian et al, (2020), observed 1.9- to 2.3fold higher pectinase production and 2.2- to 2.3 -fold higher $\alpha$-galactosidase afte $72 \mathrm{~h}$, at $\mathrm{pH} 6$ and 7 for the utilistion in environment friendly enzymatic processing.

\section{Application of pectinase in wastewater treatment}

The wastewater from the citrus-processing industry contains pectinaceous materials that are barely decomposed by microbes during the activated-sludge treatment (Tanabe et al., 1986). Tanabe et al. (1987) has tried to develop a new wastewater treatment process by using an alkalophilic microorganism. Their soil isolate an alkalophilic Bacillus sp. (GIR 621), produced an extracellula endopectate lyase in alkaline media at $\mathrm{pH} 10.0$. Treatment with this strain has proved to be useful in removing pectic substances from the wastewater.

Treatment of waste water generated through various industries such as paper processing industries, food processing industries and agro-based industries is a challenge since it releases various plant polysaccharides such as starch and pectin. Waste water treatment can be done through chemical, physical and enzymatic methods. Chemical methods utilized for the treatment waste water are harsh on the environment and cause direct or indirect environmental pollution. Alternatively, enzymes are utilized; enzymes such as pectinase is utilized for the pre-treatment of pectin rich wastewater generated through above mentioned industries before releasing the water to streams, rivers (Pitambri and Jai, 2019)

\section{CONCLUSION AND FUTURE PERSPECTIVE}

Pectinases are most potent enzyme of the commercial sector with numerous industrial applications due to its extraordinary properties to catalyze various reactions with suitable environmental parameters. Previous reports revealed that pectinolytic enzymes have two major targets: first, production of pure pectinolytic enzyme cocktail with improved properties and stability is required for various industrial processes. Second, new and cheaper sources are required for the production of cost-effective commercial pectinases for the potential market. Alkaline pectinases are the major enzyme of textile and paper industry. Genetic engineering is promising approach to produce pure pectinolytic cocktails in very small time slot. Also, conventional optimization techniques are encouraging for the pure pectinolytic cocktail synthesis. Major stable and advanced pectinolytic enzymes can be produced using advanced protein engineering techniques to achieve improved properties and activities by in-vitro modifications of protein primary structure. It will be of utmost significance for the advancement in alkaline pectinase properties

\section{REFERENCES}

Abdulrachman, D., Thongkred, P., Kocharin, K., Nakpathom, M., Somboon, B., Narumol, N., \& Chantasingh, D. (2017). Heterologous expression of Aspergillus aculeatus endo-polygalacturonase in Pichia pastoris by high cell density fermentation and its application in textile scouring. BMC biotechnology, 17(1), 15 https://doi.org/10.1186/s12896-017-0334-9

Aguilar, G., \& Huitron, C. (1987). Stimulation of the production of extracellular pectinolytic activities of Aspergillus sp. by galactouronic acid and glucose addition. Enzyme and Microbial Technology, 9(11), 690-696. https://doi.org/10.1016/0141-0229(87)90129-3

Ahlawat, S., Dhiman, S.S., Battan, B., Mandhan, R.P., Sharma, J. (2009). Pectinase production by Bacillus subtilis and its potential application in biopreparation of cotton and micropoly fabric. Process Biochemistry, 44(5), 521-526. https://doi.org/10.1016/j.procbio.2009.01.003

Ahmed, I., Zia, M.A., Hussain MA, Akram Z, Naveed MT, Nowrouzi A (2016) Bioprocessing of citrus waste peel for induced pectinase production by Aspergillus niger; its purification and characterization. Journal of Radiation Research and Applied Sciences 9(2):148-154. https://doi.org/10.1016/j.jrras.2015.11.003

Ali, S. B. R., Muthuvelayudham, R., \& Viruthagiri, T. (2013). Statistical optimization of medium components for hemicellulase production using tapioca stem. Journal of Microbiology, Biotechnology and Food Sciences, 2(6), 23772382.

Alimardani-Theuil P, Gainvors-Claisse A, Duchiron F (2011) Yeasts: An attractive source of pectinases-From gene expression to potential applications: A review. Process Biochemistry https://doi.org/10.1016/j.procbio.2011.05.010

Almeida C, Branyik T, Moradas-Ferreira P, Teixeira J (2003) Continuous production of pectinase by immobilized yeast cells on spent grains. Journal of bioscience and bioengineering 96(6):513-518. https://doi.org/10.1016/s13891723(04)70142-5

Alkorta, Garbisu C, Llama MJ, Serra JL (1998) Industrial applications of pectic enzymes: a review. Process Biochemistry 33(1):21-28. https://doi.org/10.1016/s0032-9592(97)00046-0

Amin F, Bhatti HN, Bilal M, Asgher M (2017) Multiple parameter optimizations for enhanced biosynthesis of exopolygalacturonase enzyme and its application in fruit juice clarification. Int J Food Eng 13(2):256. https://doi.org/10.1515/ijfe2016-0256

Angelim AL, Costa SP, Farias BCS, Aquino LF, Melo VM M (2013) An innovative bioremediation strategy using a bacterial consortium entrapped in chitosan beads. Journal of environmental management127:10-17. https://doi.org/10.1016/j.jenvman.2013.04.014

Arevalo-VillenaM, Fernandez M, Lopez J, Briones A (2011) Pectinases yeast production using grape skin as carbon source. Advances in Bioscience and Biotechnology 2(02): 89. https://doi.org/10.4236/abb.2011.22014

Barman, S., Sit, N., Badwaik, L. S., \& Deka S. C. (2014). Pectinase production by Aspergillus niger using banana (Musa balbisiana) peel as substrate and its effect on clarification of banana juice. J Food Sci Technol. 52(6), 3579-3589. https://doi.org/10.1007/s13197-014-1413-8

Berbegal C, SpanoG, Tristezza M, Grieco F, Capozzi V (2017) Microbial resources and innovation in the wine production sector. South African Journal of Enology and Viticulture 38(2):156-166. https://doi.org/10.21548/38-2-1333

Bilal M, Asgher M, Iqbal HM, Ramzan M (2017). Enhanced bio-ethanol production from old newspapers waste through alkali and enzymatic delignification. Waste and Biomass Valorization 8(7):2271-2281 https://doi.org/10.1007/s12649-017-9871-7.

Bilal M, Asgher M, Ramzan M (2015) Purification and biochemical characterization of extracellular manganese peroxidase from Ganoderma lucidum IBL-05 and its application. Scientific research and Essays 10(14):456-464. https://doi.org/10.5897/sre2015.6268

Bruhlman F, Kim KS, Zimmerman W, Fiechter A (1994) Pectinolytic enzymes from actinomycetes for the degumming of ramie bast fibers. Appl Environ Microbiol60:2107-2112. https://doi.org/10.1128/aem.60.6.2107-2112.1994 Couto SR, Sanroman MA (2006) Application of solid-state fermentation to food industry-A review. Journal of Food Engineering 76(3):291-302. https://doi.org/10.1016/j.jfoodeng.2005.05.022 
Demir H, Tar1 C (2014) Valorization of wheat bran for the production of polygalacturonase in SSF of Aspergillus sojae. Industrial Crops and Products54:302-309. https://doi.org/10.1016/j.indcrop.2014.01.025

Diaz-Godinez G, Soriano-Santos J, Augur C, Viniegra-Gonzalez G (2001) Exopectinases produced by Aspergillus niger in solid-state and submerged fermentation: a comparative study. Journal of Industrial Microbiology and Biotechnology 26(5):271-275. https://doi.org/10.1038/sj.jim.7000113

Djordjevic V, Willaert R, Gibson B, Nedovic V (2017) Immobilized yeast cells and secondary metabolites. Fungal Metabolites 599-638. https://doi.org/10.1007/978-3-319-25001-4 33

Enshasy, El., Elsayed, H.A., Suhaimi, E.A., N. et al. (2018). Bioprocess optimization for pectinase production using Aspergillus niger in a submerged cultivation system. BMC Biotechnol 18, 71 https://doi.org/10.1186/s12896-018$0481-7$

Favela-Torres E, Volke-Sepulveda T, Viniegra-Gonzalez G (2006) Production of Hydrolytic Depolymerising Pectinases.Food Technology \& Biotechnology 44(2):221-227.

Fawole, O.B., \& Odunfa, S.A. (2003). Some factors affecting production of pectic enzymes by Aspergillus niger. International Biodeterioration and Biodegradation, 52(4), 223-227. https://doi.org/10.1016/S0964-8305(03)00094-5

Gophanea S.R., Khobragadea C.N., and Jayebhayea S.G. (2016) Extracellular pectinase activity from Bacillus Cereus GC subgroup a: isolation, production, optimization and partial characterization. Journal of Microbiology, Biotechnology and Food Sciences, 6(2), 767-772. https://doi.org/10.15414/jmbfs.2016.6.2.767772

Glinka EM, Liao YC (2011) Purification and partial characterization of pectin methylesterase produced by Fusarium asiaticum. Fungal Biol 115(11):1112- 1121 https://doi.org/10.1016/j.funbio.2011.07.005

Goncalves DB, Teixeira JA, Bazzolli DMS, de Queiroz MV, de Araujo EF (2012) Use of response surface methodology to optimize production of pectinases by recombinant Penicillium griseoroseum T20. Biocatalysis and Agricultural Biotechnology 1(2):140-146. https://doi.org/10.1016/j.bcab.2011.09.002

Gupta S, Kapoor M, Sharma, KK, Nair LM, Kuhad RC (2008) Production and recovery of an alkaline exo-polygalacturonase from Bacillus subtilis RCK under solid-state fermentation using statistical approach. Bioresour Technol 99(5):937945. https://doi.org/10.1016/j.biortech.2007.03.009

Handa S, Nivedita S, Shruti P (2016) Multiple Parameter Optimization for Maximization of Pectinase production by Rhizopus sp. C4 under Solid State Fermentation. Fermentation https://doi.org/10.3390/fermentation2020010

Hamid S, Bhatti HN, Qayyum UA (2008) Enhanced Production of ExoPolygalacturonase by Fusarium solaniin Solid-State Fermentation. Asian Journal of Chemistry 20(6):4273-4281.

Hours, R.A., Voget, C.E. \& Ertola, R.J. (1988). Some factors affecting pectin-ase production from apple pomace in solid-state-cultures. Biol. Wastes, 24: 147157. https://doi.org/10.1016/0269-7483(88)90057-2

Hoondal G, Tiwari R, Tewari R, Dahiya NBQK, Beg Q (2002) Microbial alkaline pectinases and their industrial applications: a review. Applied microbiology and biotechnology 59(4-5):409-418. https://doi.org/10.1007/s00253-002-1061-1

Irshad M, Anwar Z, Mahmood Z, Aqil T, Mehmmod S, Nawaz H (2014) Bioprocessing of agro-industrial waste orange peel for induced production of pectinase by Trichoderma viridi; its purification and characterization. Turkish Journal of Biochemistry 39(1):9-18. https://doi.org/10.5505/tjb.2014.55707

Jahan N, Shahid F, Aman A, Mujahid TY, Qader SAU (2017) Utilization of agro waste pectin for the production of industrially importan polygalacturonase. Heliyon 3(6):

https://doi.org/10.1016/j.heliyon.2017.e00330

Jacob N (2009) Biotechnology for agro-industrial residues utilization, Part IV: Enzymes Degrading Agro-Industrial Residues and Their Production, Chapter 21 Pectinolytic Enzymes.Springer India 383-396.

Karam, N. E., \& Belarbi, A. (1995) Detection of polygalacturonases and pectin esterases in lactic acid bacteria. World J Microbiol Biotechnol, 11(5): 559-563. https://doi.org/10.1007/bf00286373

Kapoor M, Beg QK, Bhushan B, Dadhich KS, Hoondal GS (2000) Production and partial purification and characterization of a thermo-alkali stable polygalacturonase from Bacillus sp. MG-cp-2. Process Biochemistry 36(5):467473. https://doi.org/10.1016/s0032-9592(00)00238-7

Kapoor M, Kuhad RC (2000) Improved polygalacturonase production from Bacillus sp. MG-cp-2 under submerged (SmF) and solid state (SSF) fermentation.Lett Appl Microbiol 34(5):317-322. https://doi.org/10.1046/j.1472765x.2002.01107.x

Kashyap, D.R., Chandra, S., Kaul, A., \& Tewari R. (2000). Production, purification and characterization of pectinase from a Bacillus sp. DT7, World Journal of Microbiology and Biotechnology, 16(3), 277-282. https://doi.org/10.1023/A:1008902107929

Kashyap DR, Vohra PK, Chopra S, Tewari R (2001) Applications of pectinases in the commercial sector: a review. Bioresour Technol 77(3): 215- 227 https://doi.org/10.1016/s0960-8524(00)00118-8
Kashyap DR, Soni SK, Tewari R (2003) Enhanced production of pectinase by Bacillus sp. DT7 using solid state fermentation. Bioresource Technology 88(3):251-254. https://doi.org/10.1016/s0960-8524(02)00206-7 Kavuthodi, B., Thomas, S. K., \& Sebastian, D. (2015). Co-production of Pectinase and Biosurfactant by the Newly Isolated Strain Bacillus subtilis BKDS1. Br Microbiol Res J, 10(2). https://doi.org/10.9734/bmrj/2015/19627

Kavuthodi, B. \& Sebastian, D. (2018). Review on bacterial production of alkaline pectinase with special emphasis on Bacillus species. Biosci. Biotech. Res. Comm. 11(1): 18-30. https://doi.org/10.21786/bbrc/11.1/4

Khairnar Y, Krishna VK, Boraste A, Gupta N, Trivedi S, Patil P, Joshi B (2009) Study of pectinase production in submerged fermentation using different strains of Aspergillus niger. International journal of microbiology research1 (2):13 https://doi.org/10.9735/0975-5276.1.2.13-17

Khan M, Nakkeeran E, Umesh-Kumar S (2013) Potential application of pectinase in developing functional foods. Annu Rev Food Sci Technol4:21-34. https://doi.org/10.1146/annurev-food-030212-182525

Li Z, Bai Z, Zhang B, Xie H, Hu Q, Hao C, Zhang H (2005) Newly isolated Bacillus gibsonii S-2 capable of using sugar beet pulp for alkaline pectinase production. World Journal of Microbiology and Biotechnology 21(8-9):14831486. https://doi.org/10.1007/s11274-005-7025-8

Li Z, Bai Z, Zhang B, Li B, Jin B, Zhang M, Zhang H (2012) Purification and characterization of alkaline pectin lyase from a newly isolated Bacillus clausii and its application in elicitation of plant disease resistance. Applied biochemistry and biotechnology 167(8):2241-2256. https://doi.org/10.1007/s12010-012-9758-9

Maria, F. S., Teixeira J. L. Lima F., \& Nelson D. (2000). Carbon sources effect on pectinase production from Aspergillus japonicus 586, Brazilian journal of microbiology, 31, 286-290. https://doi.org/10.1590/s1517-83822000000400009

Martos MA, Zubreski ER, Garro OA, Hours RA (2013) Production of Pectinolytic Enzymes by the Yeast Wickerhanomyces anomalus Isolated from Citrus Fruits Peels.Biotechnol Res Int 43:51-54. https://doi.org/10.1155/2013/435154

Matsumoto, H., Jitareerat, P., Baba, Y., \& Tsuyumu, S. (2003) Comparative study of regulatory mechanisms for pectinase production by Erwinia carotovora subsp. carotovora and Erwinia chrysanthemi. Molecular plant-microbe interactions, 16(3), 226-237. https://doi.org/10.1094/mpmi.2003.16.3.226

Moreno-Garcia J, Garcia-Martinez T, Mauricio JC, Moreno J (2018) Yeast Immobilization Systems for Alcoholic Wine Fermentations: Actual Trends and Future Perspectives. Frontiers in Microbiology 9:241. https://doi.org/10.3389/fmicb.2018.00241

Mohandas A, Sindhu Raveendran, Binod Parameswaran, Amith Abraham, Raj SR Athira, Anil Kuruvilla Mathew, Ashok Pandey (2018) Production of Pectinase from Bacillus sonorensis MPTD1. Food Technol. Biotechnol 56(1):110-116.

Munir N, Asgher M, Tahir IM, Riaz M, Bilal M, Shah SA (2015) Utilization of agro-wastes for production of ligninolytic enzymes in liquid state fermentation by Phanerochaete chrysosporium-IBL-03. IJCBS 7:9-14.

Murugan, T., Deepika, P., Kowsalya, A., Sivasubramanian, K., Rejisha, R.P., Murugan, M. Wins, J. A. (2020), Production and characterization of extracellular pectinase from a newly isolated Bacillus species from fruit waste soil, Materials Today:

(45):2087 - 2090 https://doi.org/10.1016/j.matpr.2020.09.607

Nedovic V, Gibson B, Mantzouridou TF, BugarskiB, Djordjevic V, Kalusevic A, Yilmaztekin M (2015) Aroma formation by immobilized yeast cells in fermentation processes. Yeast 32(1):173-216. https://doi.org/10.1002/yea.3042

Ouattara HG, Reverchon S, Niamke SL, Nasser W (2011) Molecular identification and pectate lyase production by Bacillus strains involved in cocoa fermentation. Food

https://doi.org/10.1016/j.fm.2010.07.020

Padma PN, Anuradha K, Reddy G (2011) Pectinolytic yeast isolates for cold-active polygalacturonase production. Innovative food science \& emerging technologies 12(2):178-181. https://doi.org/10.1016/j.ifset.2011.02.001

Patil, S.R. \& Dayanand, A. (2006). Production of pectinase from deseeded sunflower head by Aspergillus niger in submerged and solid-state conditions. Bioresour. Technol., $\quad 97, \quad 2054-2058$. https://doi.org/10.1016/j.biortech.2005.09.015

Pedrolli DB, Carmona EC (2010) Purification and characterization of the exopolygalacturonase produced by Aspergillus giganteus in submerged cultures. J Ind Microbiol Biotechnol 37(6):567-573. https://doi.org/10.1007/s10295-010$\underline{0702-0}$

Phutela, U., Dhuna, V., Sandhu, S., \& Chadha, B.S. (2005). Pectinase and polygalacturonase production by Thermophilic Aspergillus fumigatus isolated from decomposting orange peels. Braz $\mathrm{J}$ Microbiol 36(1): 63- 69 . https://doi.org/10.1590/S1517-83822005000100013

Qian Li, Christopher S. Ray, Nicholas V. Callow, Abdullah A. Loman, S.M.M. Islam, Lu-Kwang Ju, Aspergillus niger production of pectinase and $\alpha$ galactosidase for enzymatic soy processing, Enzyme and Microbial Technology, Volume $\quad 134, \quad 2020, \quad 109476, \quad$ ISSN $0141-0229$, https://doi.org/10.1016/j.enzmictec.2019.109476.

Rangarajan V, Rajasekharan M, Ravichandran R, Sriganesh K, Vaitheeswaran V (2010) Pectinase production from orange peel extract and dried orange peel solid as substrates using Aspergillus niger. Int J Biotechnol Biochem 6(3):445-453 
Rasheedha, A.B., Kalpana, M.D., Gnanaprabhal, G.R., Pradeep, B.V., \& Palaniswamy, M. (2010). Production and characterization of pectinase enzyme from Penicillium chrysogenum. Ind $\mathrm{J}$ Sci Technol 3: 377-381. https://doi.org/10.17485/ijst/2010/v3i4.10

Ramirez-Tapias, Y. A., Rivero, C. W., Britos, C. N., \& Trelles, J. A. (2015) Alkaline and thermostable polygalacturonase from Streptomyces halstedii ATCC 10897 with applications in waste waters. Biocatal Agric Biotechnol, 4(2): 221-228. https://doi.org/10.1016/j.bcab.2014.12.004

Reda, A.B., Yassin, H.M., Swelim, M.A., \& Ebtsam, A. Z. (2008). Production of bacterial pectinase(s) from agro-industrial wastes under solid state fermentation conditions. Journal of Applied Sciences Research, 4(12), 1708-1721.

Rehman HU, Qader SA, Aman A (2012) Polygalacturonase: production of pectin depolymerising enzyme from Bacillus licheniformis KIBGE IB-21. Carbohydr Polym 90(1):387-391. https://doi.org/10.1016/j.carbpol.2012.05.055

Roy K, Dey S, Uddin M, Barua R, Hossain M (2018) Extracellular Pectinase from a Novel Bacterium Chryseobacterium indologenes Strain SD and Its Application in Fruit Juice Clarification. Enzyme research. 1-7. https://doi.org/10.1155/2018/3859752

SaadounI, Dawagreh A, Jaradat Z, Ababneh Q (2013) Influence of Culture Conditions on Pectinase Production by Streptomyces sp. (Strain J9).International Journal of Life Science and Medical Research 3(4):148-154.

Sandri IG, Lorenzoni CMT, Fontana RC, da Silveira MM (2013) Use of pectinases produced by a new strain of Aspergillus niger for the enzymatic treatment of apple and blueberry juice. LWT-Food Science and Technology 51(2):469-475 https://doi.org/10.1016/i.lwt.2012.10.015

Sapunova, L.I., (1990). Pectinohydrolases from Aspergillus alliaceus Biosynthesis Characteristic Features and Applications. Institute of Microbiology Belarussian Academy of Science, Minsk.

Sharma D C, Satyanarayana T (2006) A marked enhancement in the production of a highly alkaline and thermostable pectinase by Bacillus pumilus dcsr1 in submerged fermentation by using statistical methods. Bioresource Technology 97(5):727-733. https://doi.org/10.1016/j.biortech.2005.04.012

Silva D, Martins ESD, Silva RD, Gomes E (2002) Pectinase production by Penicillium viridicatum RFC3 by solid state fermentation using agricultural wastes and agro-industrial by-products. Braz J Microbiol 33:318-324 https://doi.org/10.1590/s1517-83822002000400008

Sohail, M., \& Latif, Z. (2016) Phylogenetic Analysis of Polygalacturonase producing Bacillus and Pseudomonas isolated from plant waste material Jundishapur J Microbiol, 9(1), e28594. https://doi.org/10.5812/jim.28594.

Tanabe, H., Kobayashi, Y. and Akamatsu, I. (1986). Pretreatment of pectic wastewater from orange canning by soft-rot Erwinia carotovora. J. Fermentation Technol., 64: 265-268. https://doi.org/10.1016/0385-6380(86)90110-x

Tanabe, H., Yoshihara , K., Tamura, K., Kobayashi, Y., Akamatsu, I., Niyomwan, N., and Footrakul, P. (1987). Pretreatment of pectic wastewater from orange canning process by an alkalophilic Bacillus sp. J. fermentaiion Technol., 65 (2): 243 - 246. https://doi.org/10.1016/0385-6380(87)90173-7

Tanabe H, Kobayashi Y, Akamatsu I (1988) Pretreatment of pectic wastewate with pectate lyase from an alkalophilic Bacillus sp. Agricultural and biological chemistry 52(7):1855-1856. https://doi.org/10.1080/00021369.1988.10868946

Taskin M (2013) Co-production of tannase and pectinase by free and immobilized cells of the yeast Rhodotorula glutinis MP-10 isolated from tannin-rich persimmon (Diospyros kaki L.) fruits. Bioprocess and biosystems engineering 36(2):165-172 https://doi.org/10.1007/s00449-012-0771-8

Thakur P., Mukherjee G. (2021) Utilization of Agro-waste in pectinase production and its industrial application. In: Prasad R., Kumar V., Singh J., Upadhayaya C.P. (eds) Recent Developments in Microbial Technologies. Environmental and Microbail Biotechnology.

Teixeira MF, Lima Filho JL, Duran N (2000) Carbon sources effect on pectinase production from Aspergillus japonicus 586. Brazilian Journal of Microbiology 31(4):286-290. https://doi.org/10.1590/s1517 83822000000400009

Ustok FI, Tari C, Gogus N (2007) Solid-state production of polygalacturonase by Aspergillus sojae ATCC 20235. Journal of Biotechnology 127(2):322-334. https://doi.org/10.1016/j.jbiotec.2006.07.010

Viniegra-Gonzaleza GE, FT, Cristobal Noe Aguilarb, Sergio de Jesus RomeroGomeza, Gerardo Diaz-Godinez, Christopher Augurd (2003) Advantages of fungal enzyme production in solid state over liquid fermentation systems.Biochemical Engineering Journal 13:157-167. https://doi.org/10.1016/S1369-703X(02)00128$\underline{6}$

Ward OP, Forgarty WM (2010) Polygalacturonase lyase production by Bacillus subtilis and Flavobacterium pectinovorum. Appl. Microbio27:346-350. https://doi.org/10.1128/am.27.2.346-350.1974

Willats WG, Knox JP, Mikkelsen JD (2006) Pectin: new insights into an old polymer are starting to gel. Trends in Food Science \& Technology 17(3):97-104. https://doi.org/10.1016/j.tifs.2005.10.008

Wong LY, Saad WZ, Mohamad R, Tahir PM (2017) Optimization of cultural conditions for polygalacturonase production by a newly isolated Aspergillus fumigatus R6 capable of retting kenaf. Ind Crops Prod 97:175-183. https://doi.org/10.1016/j.indcrop.2016.12.019
Yu P, Zhang Y, Gu D (2017) Production optimization of a heat-tolerant alkaline pectinase from Bacillus subtilis ZGL14 and its purification and characterization. Bioengineered 8(5):613-623.

https://doi.org/10.1080/21655979.2017.1292188

Yoshitake S, Numata T, Katsuragi T, Hours RA, Sakai T (1994) Purification and characterization of a pectin-releasing enzyme produced by Kluyveromyces wickerhamii. Journal of fermentation and bioengineering 77(4):370-375 https://doi.org/10.1016/0922-338X(94)90006-X

Zhang J, Kang Z, Ling Z, Cao W, Liu L, Wang M, Chen J (2013) High-level extracellular production of alkaline polygalacturonate lyase in Bacillus subtilis with optimized regulatory elements. Bioresource technology 146:543-548 https://doi.org/10.1016/j.biortech.2013.07.129

Zhang J, Zhao L, Gao B, Wei W, Wang H, Xie J (2018) Protopectinase production by Paenibacillus polymyxa Z6 and its application in pectin extraction from apple pomace. Journal of Food Processing and Preservation 42(1):13367. https://doi.org/10.1111/jfpp.13367

Zhou JM, Ge XY, Zhang WG (2011) Improvement of polygalacturonase production at high temperature by mixed culture of Aspergillus niger and Saccharomyces cerevisiae. Bioresource technology 102(21):10085-10088. https://doi.org/10.1016/j.biortech.2011.08.077

Zou M, Guo F, Li X, Zhao J, Qu Y (2014) Enhancing production of alkaline polygalacturonate lyase from Bacillus subtilis by fed-batch fermentation. PloS one 9(3):90392. https://doi.org/10.1371/journal.pone.0090392

Zou M, Li X, Shi W, Guo F, Zhao J, and Qu Y (2013) Improved production of alkaline polygalacturonate lyase by homologous overexpression pelA in Bacillus subtilis. Process

https://doi.org/10.1016/j.procbio.2013.05.023
Biochemistry 48(8):1143-1150. 